Article

\title{
Strategic Pathways to Scale Up Forest and Landscape Restoration: Insights from Nepal's Tarai
}

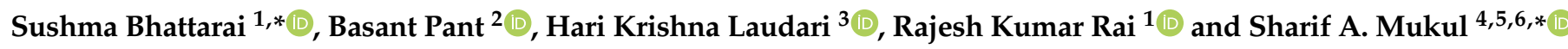 \\ 1 Institute of Forestry, Tribhuvan University, Pokhara 33700, Nepal; rjerung@gmail.com \\ 2 International Centre for Integrated Mountain Development, Kathmandu 44700, Nepal; \\ basant.pant@icimod.org \\ 3 Ministry of Forests and Environment, Kathmandu 44600, Nepal; hklaudari@gmail.com \\ 4 Tropical Forests and People Research Centre, University of the Sunshine Coast, Maroochydore DC, \\ QLD 4556, Australia \\ 5 Centre for Research on Land-Use Sustainability, Dhaka 1229, Bangladesh \\ 6 Department of Earth and Environment, Florida International University, Miami, FL 33199, USA \\ * Correspondence: bhattarai.sushma@gmail.com (S.B.); smukul@usc.edu.au (S.A.M.)
}

Citation: Bhattarai, S.; Pant, B.;

Laudari, H.K.; Rai, R.K.; Mukul, S.A. Strategic Pathways to Scale Up Forest and Landscape Restoration: Insights from Nepal's Tarai. Sustainability 2021, 13, 5237. https://doi.org/ $10.3390 /$ su13095237

Academic Editor: Axel Schwerk

Received: 8 April 2021

Accepted: 5 May 2021

Published: 7 May 2021

Publisher's Note: MDPI stays neutral with regard to jurisdictional claims in published maps and institutional affiliations.

Copyright: (c) 2021 by the authors. Licensee MDPI, Basel, Switzerland. This article is an open access article distributed under the terms and conditions of the Creative Commons Attribution (CC BY) license (https:// creativecommons.org/licenses/by/ $4.0 /)$.

\begin{abstract}
Deforestation and forest degradation mostly caused by human interventions affect the capacity of the forest ecosystem to provide ecosystem services and livelihood benefits. Forest and landscape restoration (FLR) is an emerging concept that focuses on the improvement of the ecosystem as well as the livelihood of the people at the landscape level. Nepal has successfully recovered degraded forest land mainly from the hilly region through forest restoration initiatives, especially community-based forestry. However, the Tarai region is still experiencing deforestation and forest degradation. This study navigated the gaps related to forest restoration in the existing policies and practices and revealed that the persistence of deforestation and forest degradation in Tarai is a result of a complex socioeconomic structure, the limitations of the government in implementing appropriate management modality, unplanned infrastructure, and urban development. We suggest that forest restoration should focus on ecological and social wellbeing pathways at the landscape level to reverse the trend of deforestation and forest degradation in the Tarai regions of Nepal. The study provides critical insight to the policymakers and practitioners of Nepal and other countries (with similar context) who are engaged in forest/ecosystem restoration enterprise.
\end{abstract}

Keywords: deforestation; forest degradation; forest restoration; livelihood; Bonn challenge

\section{Introduction}

Deforestation and forest degradation (hereafter referred to as D\&FD) is one of the major sources of terrestrial carbon emission [1]. The incidence of increasing D\&FD is the result of over exploitation of forest resources, agriculture expansion, urbanization, infrastructure development, and other climate induced factors [2,3]. D\&FD compromises the ability of forests to maintain the supply of ecosystem services. Forests provide various ecosystem services including provisioning services such as fuelwood, fodder, timber, food, and non-timber forest products (NTFPs) for local livelihood and social wellbeing [4]. A decline in the supply of these products threatens the livelihoods of millions of forestdependent populations [5]. Due to increased D\&FD, FLR has become both a global need and concern [6].

FLR not only contributes to improving biomass, carbon stock, and biodiversity conservation, but it also helps to support the livelihoods of forest-dependent people $[7,8]$. Several countries, including Nepal, have made various global commitments to FLR and have become the part of global conventions such as Aichi Biodiversity Target 15 of the United Nations Convention on Biological Diversity [9], and the United Nations Sustainable Development (SDG) Goal 15, which aims to "Protect, restore and promote sustainable 
use of terrestrial ecosystems, sustainably manage forests, combat desertification, and halt and reverse land degradation and halt biodiversity loss" [10-13]. The Bonn Challenge endorsed in 2014 in the New York Declaration on Forests in UN Climate Summit 2014 also attracted countries to pledge voluntarily to bring 350 million hectares of degraded and deforested land under restoration through the FLR approach $[12,14]$. Similarly, the latest United Nations Decade on Ecosystem Restoration 2021-2030 also highlighted the need for greatly increased global cooperation to restore degraded and destroyed ecosystems, including forests [15]. These international policy proposals have prioritized forest restoration as a key measure to fight against climate change, avoid species loss, and support rural livelihood [16,17]. In addition, a myriad of private and public restoration enterprises have emerged at multiple levels and scales [18].

Nepal as such has not formally committed to participate in forest restoration commitments such as the Bonn challenge [14]. However, the country has initiated forest restoration through several community-based forest management modalities since the 1970s [19]. Moreover, it has also implemented landscape programs such as Tarai Arc Landscape (TAL), Kailash Sacred Landscape Conservation and Development Initiative (KSLCDI), Kangchenjunga Landscape Conservation and Development Initiative (KLCDI), and Chitwan Annapurna Landscape (CHAL) in line with its SDG 15 commitment [20]. As a result, there is a reverse trend in D\&FD in Nepal, mid-hill in particular, and the forest cover has increased from 39.6\% in 1994 to $44.74 \%$ in 2014 [21]. However, D\&FD is still a prominent issue in other parts of the country, particularly Tarai and Siwalik regions [22]. According to Global Forest Watch, Nepal lost 48,600 hectare of tree cover between 2001 to 2020 , equivalent to a $0.94 \%$ decrease in tree cover since 2000 , and $22.5 \mathrm{Mt}$ of $\mathrm{CO}_{2}$ emissions. The result also emphasizes the need for strategic pathways required for the country to restore its deforested and degraded forest landscapes [23].

The government has attempted to restore the Tarai area through the maximum use of available lands including national forest, public lands, and private lands. The handing over of government-managed forest to the local community is considered as one of the strategies to reverse the trend of D\&FD in Tarai [24,25]. Similarly, the government has targeted the restoration of 50,000 ha in Tarai, out of which 30,000 is private land and 20,000 ha is public land, through plantation by 2024 [26]. Despite the initiatives and policy provisions regarding FLR, the annual rate of deforestation is still noteworthy with a rate of $0.44 \%$ between 2001 to 2010 [27]. If this rate remains constant until 2025, the current forest area of 314,600 ha (outside protected areas) will reduce to 301,086 ha, with a net loss of 13,574 ha of forest area (between 2015 and 2025). In addition, there are many national priority projects in Tarai areas such as Nijgadh International Airport; the construction of national electricity grids; widening and construction of east-west highways; the establishment of the capital of Sudur Paschim Province, Lumbini Province; and development of special economic zones as per the country's new federal structure, which claims the removal of a huge part of natural forests. Apart from this, the population growth in the Tarai region is at a rate of $1.75 \%$ per year, which has created heavy pressure on forest resources $[27,28]$. The forest areas are also being encroached to incorporate the rapidly increasing population. About 87,201 ha forest area was encroached in the 26 districts of this region within the year 2005 to 2009. The government has targeted the relief and revitalization of 14,000 ha of the encroached forest area during the first five years of the master plan implementation [29].

The Tarai region has 322 local governments out of 753 in Nepal. Among them, 36\% (115) do not have forests and 49\% (159) municipalities have less than 10\% area under forest cover [30]. Therefore, FLR is inevitable in this region to improve the forest access to the local people. It is thus deemed important to explore an appropriate forest restoration approach and mechanism so that the FLR initiative could provide multiple benefits: (a) by assessing the existing forest policies and programs in the Tarai. From this perspective, this study reviewed the history of the prevention of forest land degradation; (b) poverty alleviation; (c) climate change mitigation; (d) enhanced livelihood opportunities; and (e) addressing other socioecological concerns. While doing so, this study reviewed the history of forest 
management in Tarai, assessed the existing policies and programs, and proposed a pathway of change that could provide strategic feedback for expediting FLR in the Tarai region of Nepal and other countries that have similar biophysical and socioeconomic contexts.

\section{Analytical Framework}

This paper discusses the possibility of restoring the Tarai forest landscapes in the context of the Bonn Challenge and the United Nations Decade on Ecosystem Restoration. Given the context of the increasing D\&FD in Tarai Landscapes, it is imperative to act without delay by joining hands with the global initiatives. The UN Decade on Ecosystem Restoration provides a unique opportunity to combat the desertification in the Tarai region of Nepal and also support in achieving the global FLR targets as per its commitment towards SDGs [31].

A two-stage approach was adopted in this study. Stage assessed the drivers of D\&FD in the Tarai and their consequences. In addition, the policy and practice responses undertaken to halt this D\&FD were analyzed. For this, we reviewed published literature and consulted policymakers and practitioners who worked in the forest restoration initiatives. A total of 30 participants were consulted on the restoration initiatives in the country and underlying causes of D\&FD in the Tarai. The interview focused on obtaining participant responses on strengths and gaps of existing policy provisions and views on the strategies that are needed for upscaling the restoration initiatives in the Tarai region. We also analyzed the policy provisions made by the government and assessed different practices undertaken as part of the practice response with reference to the Tarai. The information of stage one provided the important groundwork for stage two, i.e., designing the pathways and strategies to restore the forest landscapes. In stage two, we proposed pathways for achieving FLR outcomes in the Tarai within the framework suggested by Erbaugh and Oldekop [5]. Though the pathways principally aim to restore forest ecosystem function and improve local livelihood and social wellbeing, they differ in their focus (Figure 1).

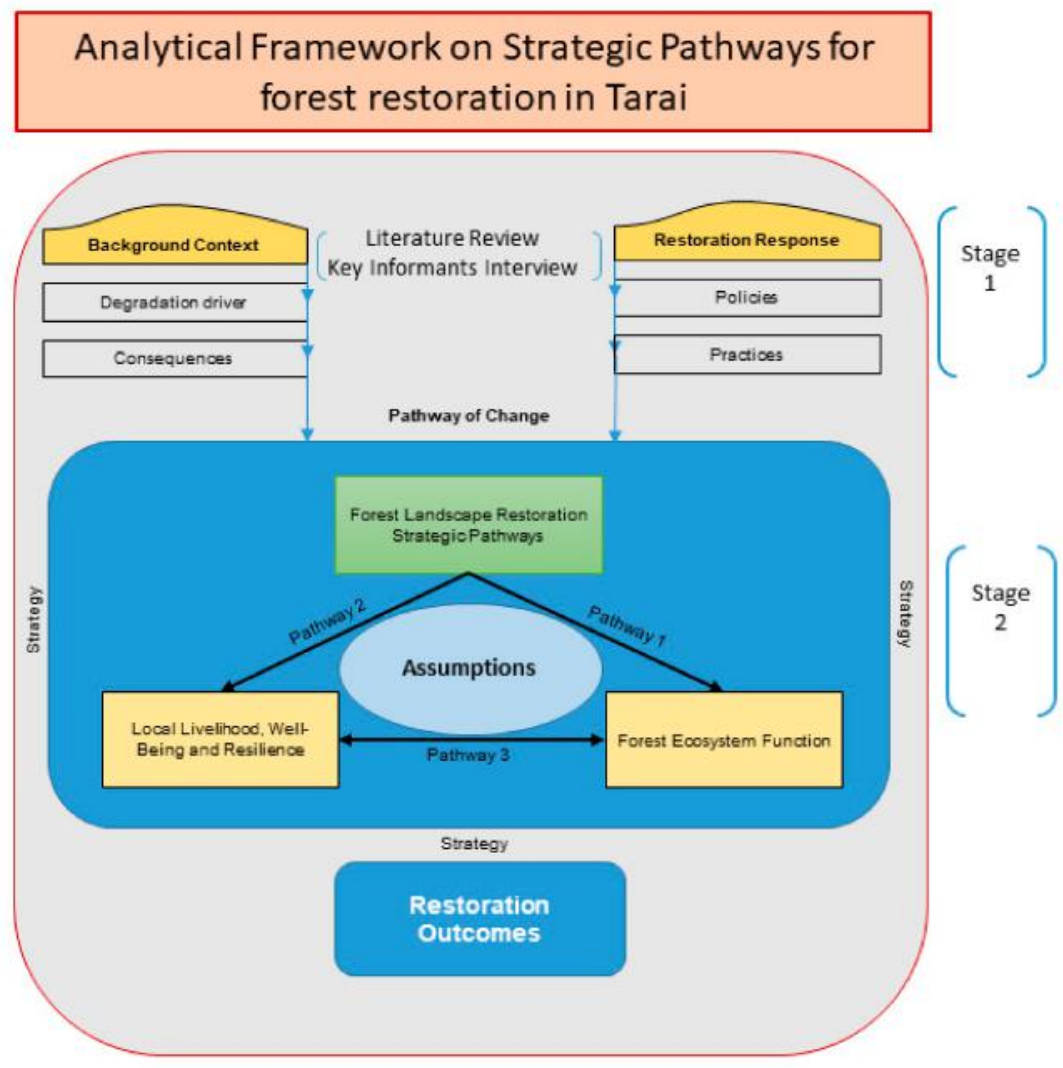

Figure 1. Analytical framework on strategic pathways for forest restoration in Tarai. 
The first pathway (Pathway 1) focuses on ecosystem recovery as its direct outcomes, which can be achieved through site preparation, plantation, agroforestry, waste land management, and flood control measures. While the recovering ecosystem also contributes to local livelihood and social wellbeing, the second pathway (Pathway 2) emphasizes improving local livelihood and enhancing social wellbeing as a primary outcome. This can also contribute to the recovery of an ecosystem. We built on this this framework to thoroughly explore and narrate the past and current FLR practices in Tarai and also draw gaps.

\section{Context of Nepal's Tarai}

Located in the 26-32 km wide transect through east to west, the Tarai physiographic region is plain and fertile land, supporting 6.9\% of the total forest area of the country [21]. Though Tarai covers only $13.7 \%$ of the total land of Nepal (Figure 2), it supports more than half of the total population of the country [28]. This region is well known for dense and highly valued Sal (Shorea robusta) forest, which harbors diverse flora and fauna (Figure 3) [32]. The Tarai region was inhabited by only indigenous Tharu and Dhanuwar communities since the region was infested with malaria until the 1960s. With the eradication of malaria, the region observed migration of communities mainly from the hilly region as part of the settlement program from the Government of Nepal and some migrants from India [33]. The increasing population pressure, urban growth, and infrastructure development negatively affected the quantity and quality of the forests over the years $[34,35]$.

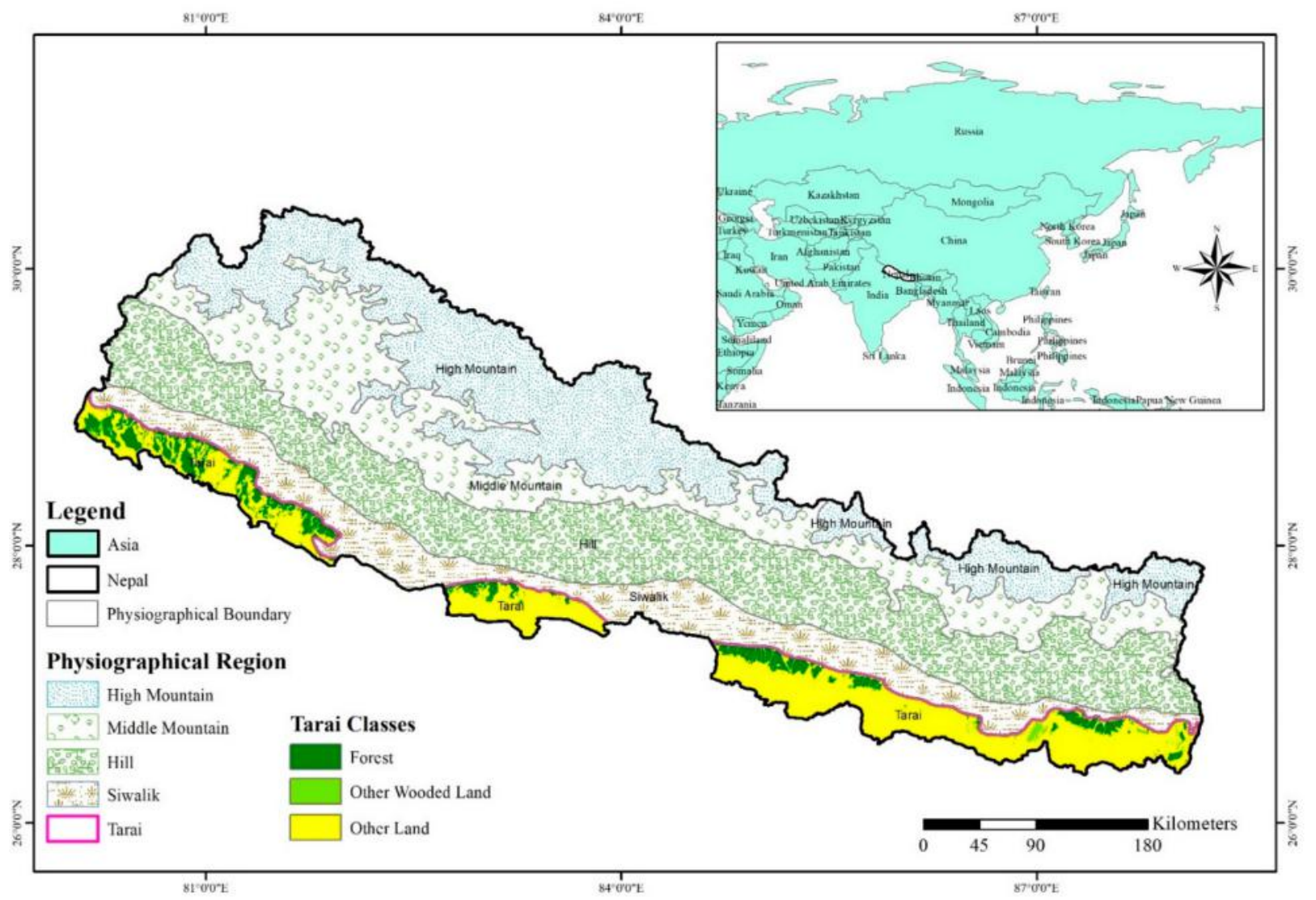

Figure 2. Location of the Tarai region in Nepal. 


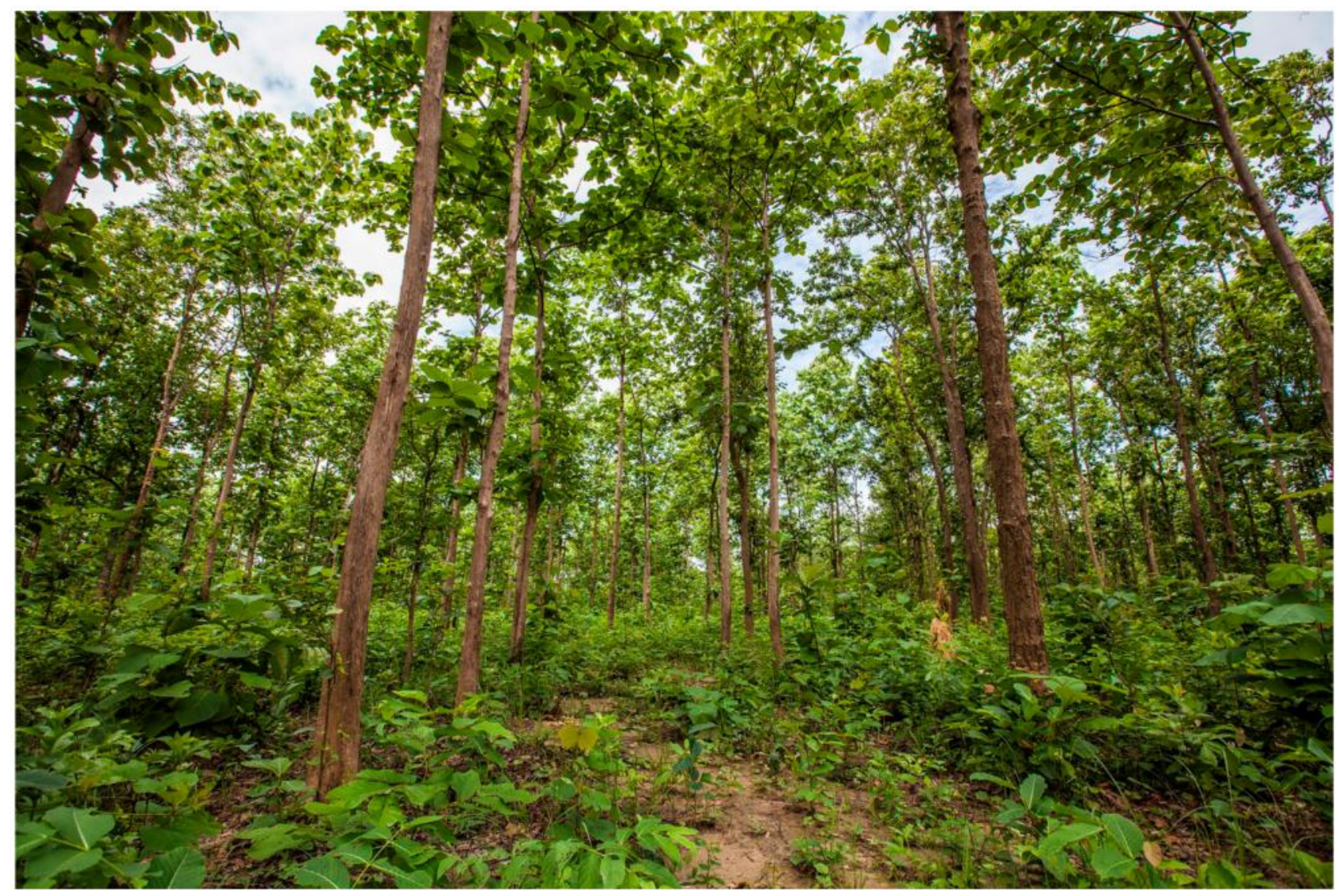

Figure 3. Tarai forest landscape of Nepal (Photo credit: Jitendra Raj Bajracharya/ICIMOD).

Due to the availability of high-value tree species, flat terrain, and productive soil, the government has exploited the land of Tarai for revenue generation [35]. The Tarai forest has undergone rapid change over the years. From 1954 to 2015, nearly $70 \%$ of the forest was lost in Tarai [33]. To reduce deforestation and manage high-value forest, the government piloted and implemented different forest management modalities, such as the Operational Forest Management Plans (OFMPs), community forestry (CF), Collaborative Forest Management (CFM), block forest management, President Chure-Tarai Madhesh Conservation and Development program, and protected areas (PAs) system. However, as attempts were not sufficient to curb D\&FD and support local livelihood [36], the Tarai is facing both deforestation and forest degradation issues [27,34].

\section{Policy Discourse and Its Interaction with Forest Degradation and Restoration Outcomes: A Decadal Analysis}

Nepal has gone through different evolutionary phases of policy development that have at times resulted in both negative and positive consequences for forest development. The institutional structures and their functions have also had a significant impact on forest restoration over the years in the country. This section navigates the historical development of forestry policies of Nepal since the 1950s and their impact on the Tarai forests (Table 1).

1950s: The Private Forest Nationalization Act 1957 has always been regarded as a major policy instrument for fueling deforestation in many parts of Nepal [37]. The act transformed the forest management under customary practices into open access resources. As a consequence, rapid deterioration of forest resulted through conversion of forested areas into farmlands through the random felling of trees across the country [38]. In addition, the government initiated a resettlement program in Tarai by inviting migrants from hilly areas to convert forest into agriculture and settlement lands [33].

1960s: During this decade, the D\&FD continued and even accelerated due to the resettlement program and because of the forest area controlled by the government. The 
government introduced the Forest Act 1961 and Forest Protection Act 1967 to curb deforestation but emphasized the felling of sal timber, mainly for export to India [39]. The government initiated some plantation projects in some areas mostly to supply raw materials [40].

1970s: A paradigm shift in the forest management approach from state-centric to local-government-centric for the Panchayat Forest (PF) and Panchayat Protected Forest (PPF) was observed during this decade, but it was limited only to mid-hill regions. The Tarai received more hill migrants as a result of the malaria eradication program, which fueled D\&FD. Protected areas (PAs) were also established. Large-scale plantation of tree species such as Dalbergia sissoo and Eucalyptus spp. started in communal and private lands to meet fuelwood and timber demand.

1980s: Policies devised during this decade primarily focused on conserving midhill forests, totally ignoring the deforestation in Tarai [40], and initiatives were more focused on increasing state control over the Tarai forests. This resulted in loss of trust among the indigenous people who were guarding the Tarai forest, therefore triggering more deforestation [35,41]. Migration from the hills continued during this decade as well. Political movements also resulted in rapid destruction of forest, and encroachment of forest area continued as well.

1990s: The expansion of CF was prevalent during this decade but in hills only, and very few community forests were handed over in Tarai as compared to hills [42]. With the aim to replicate the CF model of the hill, the Community Forestry Project and Churia Hills Community Forestry Project were initiated in Tarai and Chure regions. The Chure region is a foothill of Himalaya and is considered the youngest mountain, making it vulnerable to environmental degradation. The replication of the hills model for $\mathrm{CF}$, however, was not successful in Tarai due to the issue of distant users and conflict over benefit-sharing accrued from high value timber $[25,42,43]$. Production oriented forest management was piloted in 19 districts in Central Tarai through the development of the Operational Forest Management Plan (OFMP) [19]. This decade showed exponential growth of population [28]; thus, the Tarai region experienced more encroachment and forest degradation to provide food and shelter for growing population. Political movements such as the Maoist insurgency and the beginning of a multi-party system intensified encroachment in forest land and exploitation of natural forests of Tarai [33].

2000s: The Collaborative Forest Management modality was introduced in Tarai and mainstreamed distant users who were largely ignored by the CF program [42,44]. Public land forestry was also introduced during this period with the formation of the multistakeholder district-level platform known as the District Forest Sector Coordination Committee (DFSCC). At the same time, the corridor approach was initiated to connect PAs in the Tarai region. These initiatives, to some extent, helped restore the landscape of Nepal's Tarai.

2010s to 2020: The Government introduced scientific forest management to increase the production and productivity of Tarai forests in CFM in 2014 and expanded gradually in CF too. Similarly, $16 \%$ of the total encroached forest land was reclaimed [45]. Recently, the Emissions Reduction Program has been implemented for 14 Tarai districts to achieve $34.2 \mathrm{Mt} \mathrm{CO}_{2}$ carbon benefits (combined emission reductions and removals) over a 10-year period [34]. The forest investment plan is being implemented in Tarai. 
Table 1. An overview of policies, degradation factors, and restoration initiatives in the Tarai region between the 1950s and 2010s.

\begin{tabular}{|c|c|c|c|c|}
\hline Decade & National Policy/Legislation & Degradation Drivers & Impact & Restoration Response \\
\hline 1950s & Private Forest Nationalization Act 1957 [46] & $\begin{array}{l}\text { Migration and resettlement } \\
\text { Existing land tenure system (Birta) } \\
\text { and Raikar. }\end{array}$ & Conversion of private forest into farmland in Tarai. & $\begin{array}{l}\text { Strict protection of forest from people by } \\
\text { forming sanctuaries and using force [35]. }\end{array}$ \\
\hline 1970 & $\begin{array}{l}\text { National Forestry Plan 1976, Amendment in } \\
\text { Forest Act 1977, Panchayat Forest and } \\
\text { Panchayat Protected Forest Rules } 1978\end{array}$ & $\begin{array}{l}\text { Resettlement } \\
\text { Land use change } \\
\text { Encroachment } \\
\text { Unsustainable harvesting }\end{array}$ & Clearance of massive forest area in Tarai. & Establishment of national parks in Tarai. \\
\hline $1980 \mathrm{~s}$ & $\begin{array}{c}\text { Decentralization Act } 1982 \\
\text { Revision of PF and PPF Rules } 1987 \\
\text { Master Plan for the Forestry Sector } 1989\end{array}$ & $\begin{array}{l}\text { Encroachment } \\
\text { Unsustainable harvesting Grazing }\end{array}$ & $\begin{array}{l}\text { Theory of Himalayan proposed environmental crisis as a } \\
\text { result of forest degradation in the hills, which caused } \\
\text { flooding in the Tarai [ } 47] \text {. } \\
\text { Priority given to community forestry in the hills ignoring } \\
\text { forest loss in Tarai. Government took control of Tarai forest. }\end{array}$ & $\begin{array}{l}\text { Forest handed over to local communities as } \\
\text { community forest. }\end{array}$ \\
\hline $1990 \mathrm{~s}$ & $\begin{array}{c}\text { Forest Act } 1993 \\
\text { Forest Rules } 1995 \\
\text { Revision of Forest Act } 1999\end{array}$ & $\begin{array}{l}\text { Illegal tree felling in national forest, CF being } \\
\text { under protection in the hills } \\
\text { Forest clearing for settlement and } \\
\text { agriculture continued }\end{array}$ & $\begin{array}{l}\text { Degradation of Tarai forest continued. Government piloted } \\
\text { and tested new forest management approach [37]. }\end{array}$ & $\begin{array}{c}\text { Replication of hill model of CF, but majority } \\
\text { of community forest handed over was } \\
\text { degraded forest. } \\
\text { OFMP was prepared and implemented } \\
\text { in Tarai }\end{array}$ \\
\hline $2000 \mathrm{~s}$ & $\begin{array}{c}\text { Revised Forest Policy } 2000 \\
\text { Tarai Arc Landscape Program, which started } \\
\text { in } 12 \text { Tarai districts covering 20\% of Nepal's } \\
\text { forest (2001) } \\
\text { National Agriculture Policy } 2004 \\
\text { National NTFP Policy } 2004 \\
\text { Nepal endorsed REDD+ } 2008\end{array}$ & $\begin{array}{l}\text { Economic and infrastructure development } \\
\text { Grazing [33] }\end{array}$ & $\begin{array}{l}\text { Established collaborative forest in Tarai [42]. } \\
\text { Increased productivity, production, and environmental } \\
\text { services of the forest. Community, collaborative, leasehold, } \\
\text { protection, buffer zone, and religious and private forests are } \\
\text { identified as key tools of forest restoration. } \\
\text { National Agriculture Policy: marginal lands, pastures, } \\
\text { degraded forests and waste public lands shall be handed } \\
\text { over to target communities to support their livelihood and } \\
\text { upgrade forests and other lands. } \\
\text { Biodiversity conserved, promoted, and utilized and the } \\
\text { agroforestry system, developed in such a way as to improve } \\
\text { the condition of degraded forests and natural reservoirs. }\end{array}$ & $\begin{array}{l}\text { Replication of CF model of hills for Tarai } \\
\text { forests failed to show good results and was } \\
\text { criticized for failure to address distant users } \\
\text { and difficulty to control D\&FD. } \\
\text { Piloting of CFM in three districts, which was } \\
\text { later extended to other districts [42,44]. } \\
\text { Forestry promotion outside the forests, e.g., } \\
\text { public land forestry, agroforestry initiated in } \\
\text { some districts. }\end{array}$ \\
\hline
\end{tabular}


Table 1. Cont.

By 2020, ecosystem resilience and the contribution of biodiversity to carbon stocks has been enhanced through conservation and restoration, including restoration of at least 15 percent of degraded ecosystems.

The NBSAP contributes to Aichi Target 5 concerning loss of natural habitats and Aichi Target 7 concerning sustainable use of forest to ensure conservation of biodiversity. ERPD: The Tarai ER Program sets an ambitious but

Nepal started working on Aichi Targets National Biodiversity Strategy and Action Plan (NBSAP) 2014 [48]

Readiness Preparation Proposal 2010 Nepal submitted ERPD 2018 [34]

Land Use Policy 2015 [49]

orest Sector Strategy 2016-2025 [50]

President Chure-Tarai Madhesh

Grazing

Unsustainable tree cutting

$$
\text { Plan } 2017
$$

National REDD+ Strategy 2018 (con achieve $34.2 \mathrm{Mt} \mathrm{CO}_{2} \mathrm{e}$ in carbon

benefits (combined emissions reduction and removal) over

$$
\text { a } 10 \text {-year period. }
$$

Land use policy: If forest area is to be used for national priority projects, afforestation equivalent to those areas in size should be mandatorily undertaken.

Private sector invited for forest restoration through

partnership between state and local communities.

A reduction in deforestation rate by $0.05 \%$ is aimed for

with target rates of $0.44 \%$ and $0.18 \%$ in Tarai and Chure, respectively.

500,000 ha of forest will be managed in a 20-year period. By $2030,300,000$ ha of land will be managed as forest area. 2030, 300,000 ha of land will be man and ecosystem resilience through mitigation and adaptation approaches by minimizing the causes and adaptation approaches by minimizing the causes and
effects of the drivers of D\&FD and promoting sustainable forest management across ecological regions.
Extension of CFM.

Plantation and forestry development outside

the forest. 


\section{Pathways for Achieving FLR Outcomes}

The decadal analysis and review of policy and practice reveal that the forest land of Nepal's Tarai region is in jeopardy because of inadequate policy and institutional interventions from the government. The forest land is still under threat from a myriad of drivers, including unsustainable and illegal harvesting, overgrazing, forest fires, encroachment (from immigration and settlement in government-managed forests), resettlement (from the relocation of communities displaced by flooding along river corridors), and infrastructure development [34]. As D\&FD is associated with complex direct and indirect drivers and processes in a mosaic of socioecological systems, in-depth understanding of underlying causes of these drivers, complex structures, and processes associated with ecosystem function as well as socioeconomic issues is deemed important not only for combating the D\&FD problem in the Tarai but also for stimulating restoration practices [33]. Addressing socioecological issues related to D\&FD demands systematic and context-specific pathways that provide a clear roadmap to achieving anticipated outcomes. In this context, we propose a theory of change that provides a pathway to deal with existing problems and identify and suggest pathways of change that address the existing problem along with the assumptions related to those pathways; strategies to move along those pathways; expected changes resulting from those strategies; and restoration outcomes resulting from those changes (Figure 4).

\subsection{Pathways of Change}

5.1.1. Restoring Forest Ecosystem Functions through Rehabilitation, Reconstruction, and Reclamation of Forest Systems

This pathway intends to rehabilitate, reconstruct, and reclaim forest ecosystem function. The government of Nepal has been adopting this pathway since the 1960s and has made budgetary provisions to restore the forests through carrying out several restoration activities such as nursery establishment, seedling development, and plantation programs annually in public and private lands. Furthermore, large-scale planation, such as Dalbergia sissoo and Eucalyptus spp., was promoted; however, such large monoculture plantation faced various problems including dying and diseases. The establishment of PAs such as national parks and wildlife reserves also contributed directly to restoration outcomes. The government investments were also made through deployment of security forces (the Nepalese Army and armed forest guards) in forests and protected areas. In some cases, people were displaced from the core areas with or without compensation [51]. The pathway is successful in the rehabilitation of degraded areas, reconstruction of lands used for different purposes (for example agriculture), and reclamation of naturally degraded areas, mainly due to landslides, riverbank erosion, and flash floods. However, scholars have argued that escaping public participation has had a deleterious impact on the livelihood of affected people and detrimental effects on forest restoration outcomes [19,52]. This pathway thus has to be linked with other pathways for effective restoration results [15]. 


\section{Context}

$\rightarrow$\begin{tabular}{c|} 
Increased \\
deforestation \\
and forest \\
degradation due to \\
unplanned urban \\
development
\end{tabular}
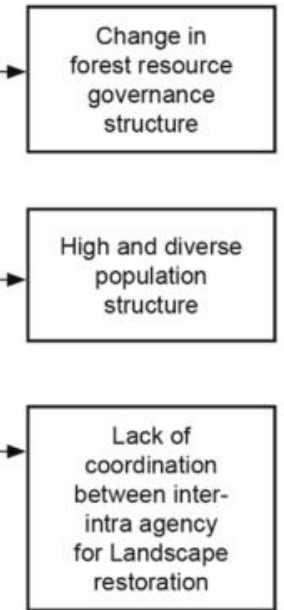

\begin{tabular}{c} 
Unsustainable \\
use of forest \\
resources resulting \\
in negative \\
effect ecosystem \\
functions and local \\
livelihood \\
\hline
\end{tabular}

Pathway of Change

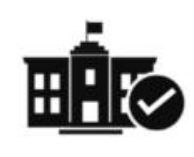

Govt. ensures the protocols and guidelines to sustain coordination

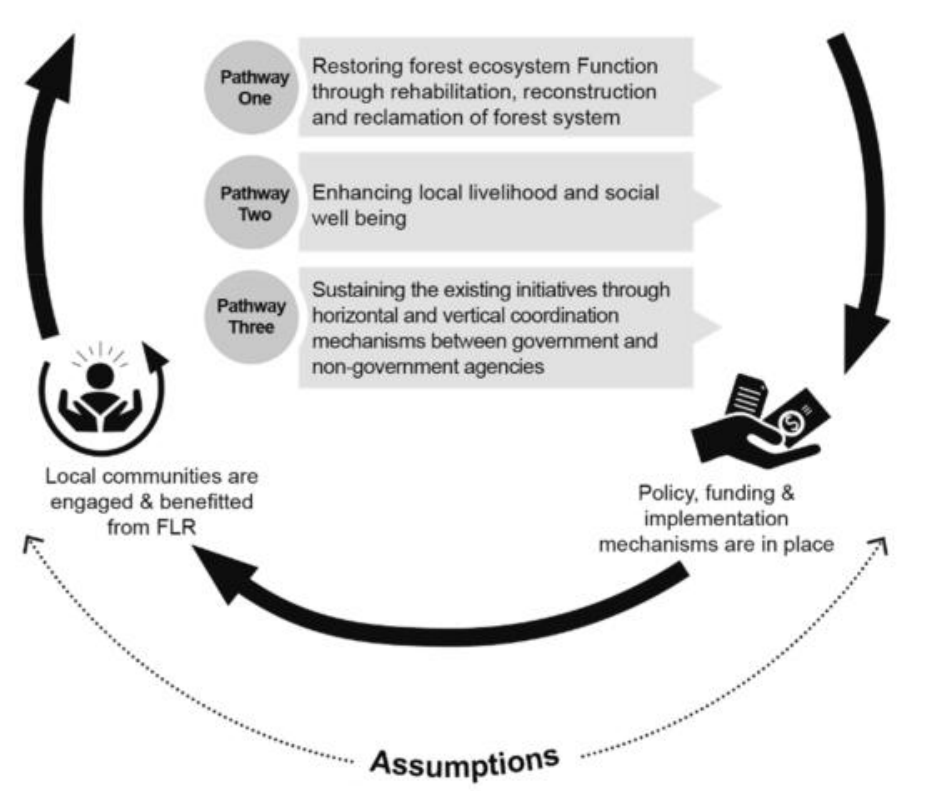

\section{Strategies}

Integrate forest storation objectives implement these plans as per land use classification

\section{Diversify livelihood options to enhance} social wellbeing

Increased plantation lands, public lands, community land

Strengthen
horizontal and
vertical cooperation
mechanism to
implement, and
monitor restoration
activities

Adopt standard protocols and procedures by respective authorities

Establish baseline data to monitor the change on ecosystem function social well being.

Create awareness among stakeholders
Restoration Outcomes

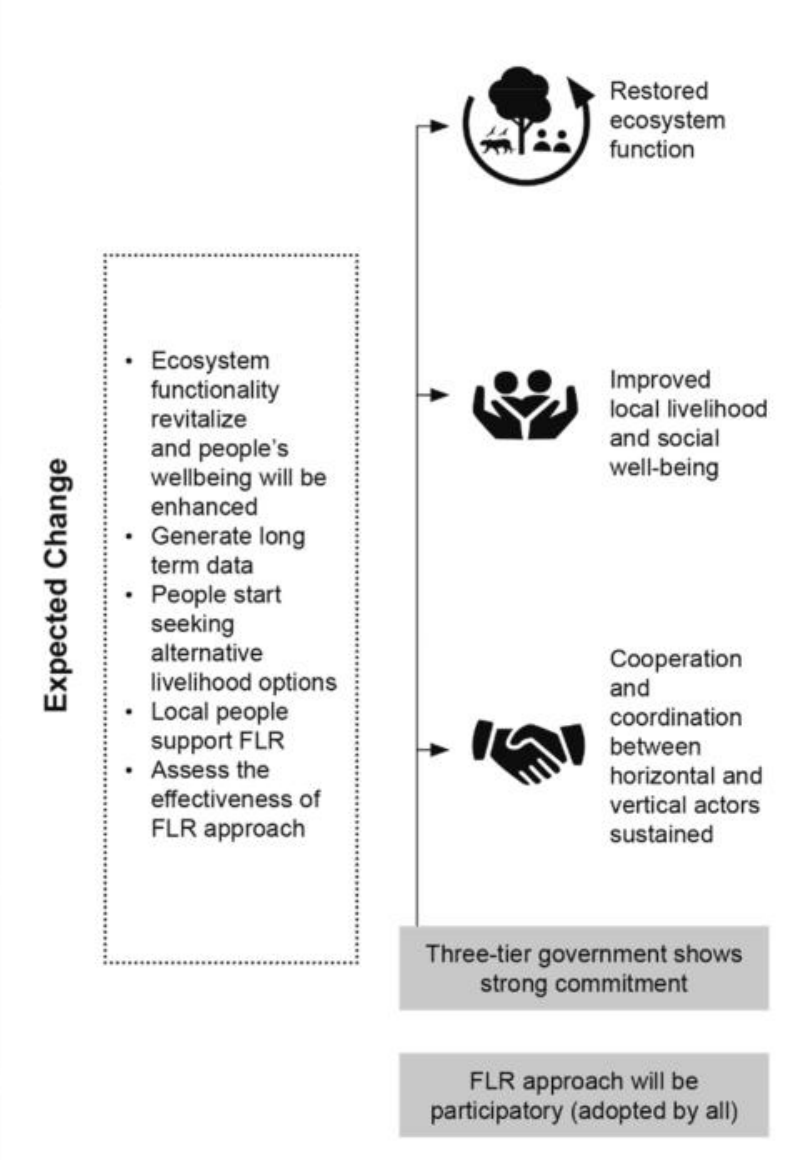

Figure 4. Schematic representation of FLR theory of change and impact pathways. 


\subsubsection{Enhancing Local Livelihood and Social Wellbeing}

One of the criteria to be considered for successful restoration is enhancing local livelihood and social wellbeing [5]. However, local livelihood and social wellbeing are often ignored in Tarai by the government. The management of Tarai forest is mainly state controlled with very low participation of local communities. Therefore, forest management approaches such as the OFMP, which was considered as a technically sound plan, failed to generate the intended outcome in Tarai because of its failure to integrate the livelihood concerns of local people. Community forestry also did not succeed to cater to the demand of indigenous and distant forest users and eventually failed [22]. To achieve restoration goals, the livelihood of the forest-dependent population has to be supported through activities such as forest-based enterprise and green economic activities such as sal leaf plate-making, bamboo furniture, and essential oil production. Nevertheless, infrastructure has to be developed to ensure the smooth functioning of such enterprises through linkage with the market, an insurance mechanism, and value addition activities. Research has suggested that interventions integrated with livelihood improvement activities reduce pressure on the forest and simultaneously help other objectives to be achieved, including forest and ecosystem restoration [52,53].

5.1.3. Sustaining the Existing Initiatives through a Horizontal and Vertical Coordination Mechanism Between Government and Non-Governmental Agencies

Landscape-level restoration requires an integrated approach involving engagement of multiple actors (both state and non-state actors), including government bodies, nongovernmental organizations, the private sector, and civil society organizations $[54,55]$. The majority of the restoration activities that were implemented in the Tarai have so far been undertaken in an isolated approach that often lacks coordination between and among the national and subnational actors. Some initiatives such as the President Chure-Tarai Conservation Program and Tarai Arc Landscape program showed successful results. Recently, Nepal has undergone massive changes in its governance structure as per the federal system, and the local government can now take the lead and bring on board government and non-government bodies in forest restoration activities. Historically, massive structural and policy changes took place regarding land use, urban development, and structural buildings. The primary indicators of these developments have resulted in a negative impact on the forest areas [38]. The Department of Forests, solely taking responsibility for forest conservation, is facing huge challenges to halt D\&FD. Restoration not only involves planting and growing trees and developing them into forest, but it also consists of maintaining the function of the ecosystem and keeping it in line with global normative change and discourse [55]. Therefore, an integrated land use plan has to be created, keeping in view the impact of development at a landscape level. Similarly, urban planning needs to be conducted so that the net effect on the forest ecosystem is null or minimal. This demands horizontal coordination among the different agencies at all levels from policy formulation to implementation and monitoring and evaluation. There is also a need to ensure vertical coordination within the appropriate ministries, departments, and grassroots-level institutions to maintain uniform understanding while putting the restoration policies and priorities into practice [54]. In a nutshell, enabling environment should be created so that all stakeholders can actively participate in designing, planning, implementing, and monitoring FLR interventions.

\subsection{Strategies for Development}

To guide the aforementioned pathways for FLR in Nepal's Tarai, we suggest the following seven strategies. 
5.2.1. Integrate Forest Restoration Objectives in Land Use Planning and Implement These Plans as per Land Use Classification

Forest restoration practices may be institutionalized only if the restoration objectives are embedded in the country's policy instruments and development plans, particularly in the land use planning. As the country has recently adopted a federal system, most of the newly restructured local-level governments lack proper land use planning. Even in cases where such planning exists, they lack the required skills and knowledge to integrate restoration strategies and implement actions for land use classification. Capacity development with regards to land use planning preparation, training, and orientation for forest restoration practices and continued support (financial and technical) for restoration activities could provide working strategies where the governments (local and provincial) can channel their investment.

\subsubsection{Diversify Livelihood Options to Enhance Social Wellbeing}

Local people of the developing countries effectively participate in the forest restoration activities only if the proposed program/initiative addresses their livelihood issues. Research has shown that the involvement of local people encourages participation, improves accountability, and increases effectiveness of the program $[53,56]$. Investment in the diversification of income sources of local people and awareness-raising programs (for ecosystem goods and services) may help to achieve the goal. Diversification of livelihood options for forest-dependent populations through the investment in forest-based enterprises and income-generating activities help to reduce direct pressure on existing forest resources and contribute to the green economy [57]. On the other hand, awareness-raising programs inform local people of ecological integrity, functionality, and goods and services of forest and other ecosystems. The provincial and local governments can invest in generating off-farm employment for the forest- and agriculture-dependent poor communities.

\subsubsection{Increase Plantation in the Underutilized Public and Community Lands}

In Tarai, the forest is located in the northern area and is mostly managed by the migrant population. The indigenous populations living in the south are devoid of access to forest resources. Plantation should be targeted to private and communal lands in these forest deficient areas. A study shows that Nepal's Tarai region has a large area of underutilized public and community lands that can be converted into the forest land with local participation [53]. Implementation of restoration activities in these lands not only helps to increase forest cover but also provides ecosystem goods and services that help to address the subsistence needs of local people and improve local livelihood [53]. The restoration activities reduce pressure on the natural forest lying in the northern part of Tarai and ensure the continued flow of ecosystem goods and services to the south. Apart from public and communal land, private forestry and agroforestry should be promoted. However, the restoration of a large chunk of Tarai's land demands huge investment from the government (local and provincial) [58]. As FLR is not a one-time event, the provincial and local governments can take the lead to gradually advance the process. At first, they may undertake an inventory of the underutilized and private lands (under their jurisdiction and rights). Secondly, they can prioritize these lands for undertaking restoration activities based on the inventory and assessment. Finally, governments can implement restoration activities through intensive coordination with the private sector and related stakeholders. Subsequent follow-up and monitoring is also required to ensure the success of the restored ecosystem after undertaking restoration activities.

5.2.4. Strengthen Horizontal and Vertical Cooperation Mechanisms to Implement and Monitor Restoration Activities

Forest restoration initiatives implemented at various scales (national and subnational) lack horizontal and vertical coordination among governments and stakeholders. Strengthening horizontal and vertical cooperation and coordination mechanisms (horizontal and 
vertical) among three-tier governments is of utmost importance to make the stakeholders aware of shared but differentiated responsibilities [37] of forest and ecosystem restoration processes and practices [54]. At the provincial and local level, coordination and cooperation mechanisms can be set up by involving relevant stakeholders including local people and the private sector. This coordination mechanism may not only augment the coordination environment between the stakeholders while undertaking forest restoration activities but also enhance uniform understanding and concerted efforts to resolve restoration jurisdiction related issues, thereby enhancing shared ownership [15].

\subsubsection{Adopt Standard Protocols and Procedures among Authorities}

Nepal has initiated FLR activities since the 1960s both in hills and Tarai. Although the country is making a substantial investment in forest restoration activities, the anticipated result, at least for the Tarai region, has not been achieved so far. This is partly because of the lack of standard protocols and procedures for FLR processes and practices. The government should accordingly develop site-specific (considering forest and ecosystems) protocols and procedures for undertaking forest restoration activities. The federal government, in this regard, can develop a guiding protocol in line with global restoration policy and practices, while the local and provincial governments may develop site-specific protocols and procedures within the overarching framework of the federal-level guidelines. These kinds of protocols and procedures may work as a guiding framework for all governments to facilitate restoration related activities. Furthermore, their versatility allows appropriate activities suiting the local environment and context to be chosen.

\subsubsection{Establish Baseline Data to Monitor the Change in Ecosystem Function and Local Livelihood and Social Wellbeing}

Nepal has set an example in participatory FLR in mid-hill areas. However, there is limited evidence on how the restoration related activities are being implemented in the Tarai region. From this perspective, the establishment of baseline data is essential to gauge the efficacy and effectiveness of implemented restoration activities and to gain insights for forest restoration related decision-making and evidence-based planning. To mainstream and institutionalize restoration discourse at subnational, local, and provincial levels, the government can start establishing baseline data and links with the national-level database. This will bridge not only the national and transnational data gaps in FLR but also ensure scientific and well-grounded ecosystem restoration planning.

\subsubsection{Create Awareness among Stakeholders}

Awareness raising is a powerful tool to change people's behavior [59]. As restoration activities are directly related to rehabilitating and restoring degraded ecosystems at least at a functional level, making the stakeholders aware of the need for ecological restoration is helpful in both enhancing people's participation and stimulating mass movement for restoration initiatives. For this, champions and role models including actors and political leaders can be selected and mobilized for awareness and capacity building activities.

\section{Conclusions}

Nepal has a long history of FLR. However, the anticipated outcome has not been achieved in Nepal's Tarai region for various reasons. The forests and communal land in the Tarai of Nepal are being exposed to threats from a myriad of drivers, including population growth, unsustainable harvesting of forest products, and unsystematic development activities. As a result, inhabitants of Tarai are deprived of access to goods and services of the forest ecosystem, and the livelihoods of the population are in jeopardy. As D\&FD is associated with complex direct and indirect drivers and processes in a mosaic of socioecological systems, in-depth understanding of underlying causes of these drivers, complex structures, and processes associated with ecosystem function as well as socioeconomic issues are deemed important not only for combating D\&FD problems but also for stimulating restoration practices. To assess whether forest and landscape restoration can be 
expedited in this region so as to address drivers of D\&FD and enhance the socioecological resilience of Tarai's communities, we propose four FLR related strategic pathways to deal with key drivers of D\&FD and recommend seven strategies to move along these pathways for resolving underlying socioeconomic causes of D\&FD in Nepal's Tarai region. As the ecological pathway alone cannot guarantee the success of the restoration program, particularly in the developing world, we argue that programs that address the socioeconomic issues of the locals also need to be integrated into the policy and planning framework of FLR. The findings and suggestions of this study may provide critical insights for the policymakers and practitioners of other countries who are engaged in forest/ecosystem restoration enterprise.

Author Contributions: Conceptualization, S.B. and B.P.; methodology, S.B., B.P., H.K.L., and R.K.R.; validation, S.B., B.P., H.K.L., R.K.R. and S.A.M.; formal analysis, S.B., B.P., H.K.L., R.K.R.; writingoriginal draft preparation, S.B., B.P., H.K.L., R.K.R.; writing-review and editing, S.B., B.P., H.K.L., R.K.R., S.A.M.; funding acquisition, S.A.M. All authors have read and agreed to the published version of the manuscript.

Funding: This research received no external funding.

Institutional Review Board Statement: Not applicable.

Informed Consent Statement: Informed consent was obtained from all subjects involved in the study.

Data Availability Statement: Not applicable.

Acknowledgments: We are very grateful to Sudip Kumar Maharjan for graphic design support for Figure 4. ICIMOD gratefully acknowledges the support of its core donors: the Governments of Afghanistan, Australia, Austria, Bangladesh, Bhutan, China, India, Myanmar, Nepal, Norway, Pakistan, Sweden, and Switzerland. Sharif A. Mukul was supported by a grant from the Centre for Research on Land-use Sustainability (Bangladesh).

Conflicts of Interest: The authors declare no conflict of interest. The views and interpretations in this publication are those of the author's and they are not necessarily attributable to their organizations.

\section{References}

1. Mukul, S.A.; Halim, M.A.; Herbohn, J. Forest Carbon Stock and Fluxes: Distribution, Biogeochemical Cycles, and Measurement Techniques. In Life on Land, Encyclopedia of the UN Sustainable Development Goals; Filho, W.L., Azul, A.M., Brandli, L., Salvia, A.L., Wall, T., Eds.; Springer: Cham, Switzerland, 2021; pp. 361-376. ISBN 9783319710655.

2. Chazdon, R.L. Beyond deforestation: Restoring forests and ecosystem services on degraded lands. Science 2008, 320, 1458-1460. [CrossRef]

3. Lewis, S.L.; Edwards, D.P.; Galbraith, D. Increasing human dominance of tropical forests. Science 2015, 349, 827-832. [CrossRef] [PubMed]

4. Landell-mills, N.; Porras, I.T. Silver Bullet or Fools' Gold? A Global Review of Markets for Forest Environmental Services and Their Impact on the Poor. In Instruments for Sustainable Private Sector Forestry Series; International Institute for Environment and Development (IIED): London, UK, 2002.

5. Erbaugh, J.T.; Oldekop, J.A. Forest landscape restoration for livelihoods and well-being. Curr. Opin. Environ. Sustain. 2018, 32, 76-83. [CrossRef]

6. MEA. Ecosystems and Human Well-Being: Synthesis; Island Press: Washington, DC, USA, 2005; ISBN 1597260401.

7. Chazdon, R.; Brancalion, P. Restoring forests as a means to many ends: An urgent need to replenish tree canopy cover calls for holistic approaches. Science 2019, 364, 24-25. [CrossRef]

8. Ota, L.; Chazdon, R.L.; Herbohn, J.; Gregorio, N.; Mukul, S.A.; Wilson, S.J. Achieving quality forest and landscape restoration in the tropics. Forests 2020, 11, 820. [CrossRef]

9. CBD. Report of the Tenth Meeting of the Conference of the Parties to the Convention on Biological Diversity, Tenth Meeting, Nagoya, Japan, 18-29 October 2010; Agenda item 5.4; United Nation Environment Program: Nagoya, Japan, 2010.

10. CBD. Decision Adopted by the Conference of the Parties to the Convention on Biological Diversity at its Seventh Meeting; United Nation Environment Program: Kuala Lumpur, Malaysia, 2004.

11. UNFCCC. Report of the Conference of the Parties on Its Fifteenth Session, Held in Copenhagen from 7 to 19 December 2009, Addendum, Part Two: Action Taken by the Conference of the Parties at Its Fifteenth Session; United Nations: Copenhagen, Denmark, 2009.

12. UN. New York Declaration on Forests: Declaration and Action Agenda 2014; United Nations: New York, NY, USA, $2014 ;$ p. 17.

13. NPC. Nepal's Sustainable Development Goals, Baseline Report; Government of Nepal: Kathmandu, Nepal, 2017.

14. IUCN. Bonn Challenge: Impact and Potential of Forest Landscape Restoration; IUCN: Gland, Switzerland, 2020. 
15. Chazdon, R.L.; Herbohn, J.; Mukul, S.A.; Gregorio, N.; Ota, L.; Harrison, R.D.; Durst, P.B.; Chaves, R.B.; Pasa, A.; Hallett, J.G.; et al. Manila declaration on forest and landscape restoration: Making it happen. Forests 2020, 11, 685. [CrossRef]

16. Bastin, J.-F.; Finegold, Y.; Garcia, C.; Mollicone, D.; Rezende, M.; Routh, D.; Zohner, C.M.; Crowther, T.W. The global tree restoration potential. Science 2019, 366, 76-79. [CrossRef]

17. Suding, K.; Higgs, E.; Palmer, M.; Callicott, J.B.; Anderson, C.B.; Baker, M.; Gutrich, J.J.; Hondula, K.L.; LaFevor, M.C.; Larson, B.M.H.; et al. Committing to ecological restoration. Science 2015, 348, 638-640. [CrossRef] [PubMed]

18. Chazdon, R.L. Making Tropical Succession and Landscape Reforestation Successful. J. Sustain. For. 2013, 32, 649-658. [CrossRef]

19. Laudari, H.K.; Aryal, K.; Bhusal, S.; Maraseni, T. What lessons do the first Nationally Determined Contribution (NDC) formulation process and implementation outcome provide to the enhanced/updated NDC? A reality check from Nepal. Sci. Total Environ. 2020, 759, 143509. [CrossRef]

20. MOFE. Annual Progress Report FY 2075/076 (2018/19); Ministry of Forests and Environment: Kathmandu, Nepal, 2019.

21. DFRS. State of Nepal's Forests, 5th ed.; Department of Forest Research and Survey (DFRS): Kathmandu, Nepal, 2015.

22. Mukul, S.A.; Byg, A. What determines indigenous Chepang farmers' Swidden land-use decisions in the central hill districts of Nepal? Sustainability 2020, 12, 5326. [CrossRef]

23. World Resources Institute Global Forest Watch: Tree Cover Loss in Nepal. Available online: https://www.globalforestwatch.org (accessed on 28 April 2021).

24. MoFSC. Nepal's Readiness Preparation Proposal REDD (2010-2013); Ministry of Forests and Environment: Kathmandu, Nepal, 2010.

25. Rai, R.K.; Nepal, M.; Karky, B.S.; Somanathan, E.; Timalsina, N.; Khadayat, M.S.; Bhattarai, N. Costs and Benefits of Reducing Deforestation and Forest Degradation in Nepal; REDD Implementation Centre: Kathmandu, Nepal, 2017.

26. NPC. 15th Five Year Plan (2019-2023): Approach Paper; National Planning Commission, Government of Nepal, Singhadurbar: Kathmandu, Nepal, 2019.

27. FRA/DFRS. Terai Forests of Nepal 2010-2012; Department of Forest Research and Survey: Kathmandu, Nepal, 2014 ; Volume 53.

28. CBS. Nepal Census 2011 District Profiles (Demography); Central Bureau of Statistics, Government of Nepal: Kathmandu, Nepal, 2011.

29. GON. President Chure-Tarai Madhesh Conservation and Management Master Plan; Ministry of Forests and Environment: Kathmandu, Nepal, 2017.

30. DFRS. Forest Cover Maps of Local Levels (753) of Nepal; Department of Forest Research and Survey: Kathmandu, Nepal, 2018.

31. UNEP/FAO. The UN Decade on Ecosystem Restoration 2021-2030; United Nations: New York, NY, USA, 2019.

32. Ministry of Forest and Soil Conservation. Nepal Biodiversity Strategy; Ministry of Forests and Soil Conservation, HMGN: Kathmandu, Nepal, 2002.

33. Ghimire, M. Historical land covers change in the chure-tarai landscape in the last six decades: Drivers and environmental consequences. In Springer Geography; Springer Nature: Singapore, 2017; pp. 109-147. ISBN 9789811028908.

34. GON. Carbon Fund Emission Reductions Program Document (ER-PD); Government of Nepal: Kathmandu, Nepal, 2018.

35. Adhikari, J.; Dhungana, H. The State and Forest Resources: An Historical Analysis of Policies Affecting Forest Management in the Nepalese Tarai. J. Assoc. Nepal Himal. Stud. 2010, 29, 4.

36. MOFE. Nepal National REDD+ Strategy; Ministry of Forests and Environment: Kathmandu, Nepal, 2018.

37. Laudari, H.K.; Aryal, K.; Maraseni, T. A postmortem of forest policy dynamics of Nepal. Land Use Policy 2020, 91, 104338. [CrossRef]

38. Pandit, R.; Bevilacqua, E. Forest users and environmental impacts of community forestry in the hills of Nepal. For. Policy Econ. 2011, 13, 345-352. [CrossRef]

39. Stewart, J. Forest Policy in Nepal: Implications for Social Forestry; Oversees Development Institute: London, UK, 1986.

40. Guthman, J. Representing Crisis: The Theory of Himalayan Environmental Degradation and the Project of Development in Post-Rana Nepal. Dev. Chang. 1997, 28, 45-69. [CrossRef]

41. Malla, Y.B. Changing policies and the persistence of patron-client relations in Nepal: Stakeholders' responses to changes in forest policies. Environ. Hist. 2001, 6, 287-307. [CrossRef]

42. Bampton, J.F.R.; Ebregt, A.; Banjade, M.R. Collaborative Forest Management in Nepal's Terai: Policy, Practice and Contestation. J. For. Livelihood 2007, 6, 30-43.

43. Rai, R.K. Nepal's Terai Forest Management: An Ethical View. In Paper Submitted for Seminar Period (March 2007); University of Joensuu: Joensuu, Finland, 2007.

44. MFSC. Forest Sector Policy 2000; Ministry of Forests and Soil Conservation: Kathmandu, Nepal, 2000.

45. MOFE. Forest Policy Nepal 2019; Ministry of Forests and Environment: Kathmandu, Nepal, 2019.

46. HMGN. Private Forests (Nationalization) Act, 1957; Nepal Gazette: Kathmandu, Nepal, 1957; pp. 1-2.

47. Ives, J.D.; Messerli, B. The Himalayan Dilemma: Reconciling Development and Conservation; United Nations University Press: London, UK; New York, NY, USA, 1989.

48. MOFE. National Biodiversity Strategy and Action Plan 2014-2020; Ministry of Forests and Environment: Kathmandu, Nepal; Government of Nepal: Kathmandu, Nepal, 2014.

49. MoLRM. Land Use Policy 2015; Ministry of Land Reform and Management: Kathmandu, Nepal; Government of Nepal: Kathmandu, Nepal, 2015.

50. GoN/MFSC. Forestry Sector Strategy (2016-2025); Ministry of Forests and Soil Conservation: Kathmandu, Nepal, 2016. 
51. Bhattarai, S.; Pant, B.; Timalsina, N. Conservation without Participation: Detrimental Effect of Escaping People's Participation in Protected Area Management in Nepal. In Protected Areas: Policies, Management and Future Directions; Mukul, S.A., Rashid, A.Z.M.M., Eds.; Nova Science Publishers: New York, NY, USA, 2017; pp. 83-104.

52. Aryal, K.; Laudari, H.K.; Ojha, H.R. To what extent is Nepal's community forestry contributing to the sustainable development goals? An institutional interaction perspective. Int. J. Sustain. Dev. World Ecol. 2020, 27, 28-39. [CrossRef]

53. Bhattarai, S.; Pant, B.; Laudari, H.K.; Timalsina, N.; Rai, R.K. Restoring landscapes through Trees Outside Forests: A case of Terai region of Nepal. Int. For. Rev. 2020, 22, 1-16. [CrossRef]

54. Mansourian, S.; Parrotta, J. From addressing symptoms to tackling the illness: Reversing forest loss and degradation. Environ. Sci. Policy 2019, 101, 262-265. [CrossRef]

55. Moreno-Mateos, D.; Alberdi, A.; Morriën, E.; van der Putten, W.H.; Rodríguez-Uña, A.; Montoya, D. The long-term restoration of ecosystem complexity. Nat. Ecol. Evol. 2020, 4, 676-685. [CrossRef] [PubMed]

56. Agrawal, A.; Redford, K. Conservation and Displacement: An Overview. Conserv. Soc. 2009, 7, 1-10. [CrossRef]

57. Oldekop, J.A.; Sims, K.R.E.; Karna, B.K.; Whittingham, M.J.; Agrawal, A. Reductions in deforestation and poverty from decentralized forest management in Nepal. Nat. Sustain. 2012, 2, 421-428. [CrossRef]

58. Dhakal, A.; Rai, R.K. Who Adopts Agroforestry in a Subsistence Economy? Forests 2020, 11, 1-15. [CrossRef]

59. Owens, S.; Driffill, L. How to change attitudes and behaviours in the context of energy. Energy Policy 2008, 36, $4412-4418$. [CrossRef] 